\title{
専門応用科目における履修効果を高めるための 授業取り組みと学びに対する学生意識
}

\author{
Teaching Practices in the Engineering Applied Subject for Enhancing \\ Educational Effects and Students' Minds to Learning

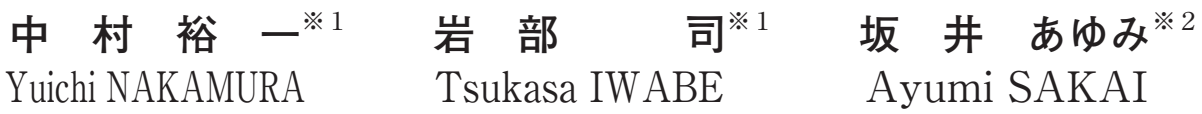

Importance of the engineering education with effective practices has recently been increased in order to enhance students' motivation to learning. This paper presents conditions of good teaching for enhancing educational effects suggested by authors and a teaching practice in the engineering applied subject. The teaching practices are evaluated from analyzing the students questionnaire of college of technology and/or university. The students' minds to learning are discussed based on the questionnaire on the conditions of good teaching by the college students. Several opinions of authors for making educational effects in teaching practices are described.

Keywords : Condition of Good Teaching, Analysis of Questionnaire, Learning Mind キーワード：良い授業の条件, アンケート分析，学びの意識

\section{1.はじめに}

「若者の理工系離れ」,「15歳・18歳人口の減少，大 学全入時代」,「基礎学力低下」などの見出しが目につ くように, 最近の高専・大学を取り巻く環境は厳しさ を増している．学びに対する意識に幅がある学生を受 け入れて育てるために必要な取り組みが求められてい るだけでなく, 教育の質の保証も課題となっている ${ }^{1)}$. このような状況の中で，JABEE（日本技術者教育認 定機構）は，「技術者教育」を推進する中心的役割を 果たしている。この「技術者教育」においては，基 礎・専門に関わる「学力」だけでなく，学びの意欲を 高めるための自己啓発力などの「人間力」も授業を通 して育てることが求められている ${ }^{2)}$ 。そして，技術の 分野で先導的な役割を果たすことの出来る人材を育て るための取り組みは如何にあるべきかを明確にし，そ れを共通理解として掲げ，実践していく必要がある. 著者の一人（中村）は，「創造型技術者に要求される 基礎学力」をテーマに揭げた平成10年度高等技術教育 フォーラムの総合報告 ${ }^{3)}$ で，次のような技術者とし て持つべき素養を示している．即ち，我々は「考えき る（つくす）力」，「行動できる力」，「人を動かす力」 を身につけた技術者を育てていく必要がある。工学。 技術教育を充実させることが必須となるが，高学年で

平成 21 年 1 月 16 日受付

※ 1 八代工業高等専門学校土木建築工学科

※ 八代工業高等専門学校総務課
学ぶ専門応用科目は，選択科目であることが多く，受 講生に科目の必要性を理解させ，学びの意欲や関心を 高めながら授業を行うことが重要である.

本論文では，まず，授業担当者として考える「良い 授業の条件」を示す．次に，それを基に授業を行った 専門応用科目での取り組み事例を示し，同じシラバス の内容で受講した高専 5 年生と大学工学部 4 年生の授 業アンケート結果を分析して, 授業取り組みの評価を 行った。また，良い授業に対する学生意識を知るため に高専生に行ったアンケート調査結果を示した。その 分析を基に，技術者を目指して意欲的な取り組みを行 うことの出来る学生を育てるための授業改善に関わる 課題を示した.

\section{2. 良い授業の条件とその取り組み}

\section{1 良い授業の条件}

学びに対する意識に幅がある学生を受け入れて育て るために, 教員の意識改革と授業改善が求められてい る。受講する学生たちに目的意識を芽生えさせ，受 講の成果を認識させるプログラムを具体的に提示す る能力も授業担当者は求められている ${ }^{4)}$. そして, 工 学・技術教育に扔いて重要な課題解決能力を育てるた めに，学ぶ意欲を向上させる実体験の機会を作り，自 分で考える力を身につけさせることが求められてい

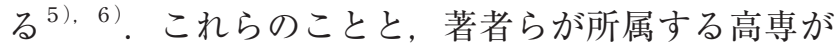
揭げる理念「自立した実践的技術者の育成」も踏まえ て，著者らが大切にしている「良い授業の条件」を以 
下に示す.

（a）科目の必要性とその内容を理解させ，受講するこ とを通して，発見や感動を意識させる。

（b）社会の要求レベルを保ちながら, 学ぼうとする取 り組みの中で, わかりやすく講義する.

(c) デイスカッションを通して, その知識と学ぶ意欲 を高めさせる.

（d）授業を通して，受講生にやれば出来るとの意識を 持たせる.

以上の項目については, 授業を通して学生の学びに 対する意欲を高め, 人間的成長を促すために，達成感 を意識させ, 自己肯定感を育てることを目的に具体化 した。

\section{2 専門応用科目での取り組み}

著者の一人（中村）が担当した専門応用科目「工業 火薬学」に扔ける「良い授業の条件」を具体化した取 り組みを示す。なお，この科目の単位取得者は，国家 資格試験である「火薬類取扱保安責任者免状試験」で の受験科目「一般火薬学」が免除となる. 担当する専 門応用科目と授業担当者の専門分野の関わりがあれ ば，学生の学ぶ意欲を高めるための取り組みを行うこ とが出来る，授業では，次のことを重視し，そのため の取り組みを行った。

（a）科目に対する興味を高め, 科目の必要性とその内 容を理解させる。このため, 施工技術に関するビデ オの活用や授業担当者が行った杭頭の動的破砕処理 工法開発 ${ }^{7)}$ に関する産学連携取り組みや知財化 ${ }^{8)}$ などの最新技術や研究成果の紹介を行った。また, 爆発デモ実験を体験させるため, 熊本大学が所有す る衝撃・極限環境研究センターの爆発実験室を使用 して, 爆薬の爆ごう速度測定を行った。

（b）基礎知識を習得させる. 授業ではパワーポイント を使用して要点を簡潔に示し，質問を通して，基礎 知識を確認した。また, 資格試験問題を演習課題と し, 社会の要求レベルを意識させた.

（c）ディスカッションを通して学生の主体的な取り組 みを促し，考える力を育てる，資格取得の意義を理 解させ, 取得意欲を高めるために, 資格試験に関す るデー夕等の資料を配布した。

(d) 開講時に, 受講意欲のある学生には単位が取得出 来るように指導することを表明するとともに, 試験 では意欲的な取り組みをした学生の評価に応えられ る出題内容とすることを意識した。定期試験での問 題レベルは, 甲種火薬類取扱保安責任者免状試験レ ベル以上とし, 学生に達成感を意識させた。

\section{3. 学生授業アンケートデータと授業評価}

3. 1 学生の授業アンケートデータ

同一内容のシラバスの授業を, 高専 5 年生（コース 必修科目）と大学 4 年生（選択科目で, 科目名は火薬
及び爆破工学)に行った。平成17年度前期の期間中に, 高専及び大学の各々で組織的なFD活動として行われ た授業アンケート（大学では12週目, 高専では13週目 の授業時に実施）における同じ意味の設問に対する評 価を以下に示す。ただし, 高専受講生21名, 大学受講 生15名のアンケートデータである，高専でのアンケー 卜結果は学生評価の平均值で示されており, 両者を比 較するために, 大学のアンケート結果で示された評価 項目に対する人数から, その評価の平均值を求めてい る.

〈共通の設問についての授業評価データ〉

（a）授業の進行の速さの適切さ

(適切; 5 , 不適切 ; 1 )

高専生……3.5 大学生……4.5

(b) 板書の仕方の適切さ

(非常に適切； 5, 不適切； 1 )

高専生……2.9 大学生……3.9

(c) 授業における工夫

（非常に工夫； 5 ，工夫なし； 1)

高専生 $\cdots \cdots \cdot 4.2$ 大学生 $\cdots \cdots \cdot 4.7$

（d）教科書や配布資料の適切さ

(適切; 5 , 不適切 ; 1 )

高専生……3.8 大学生……4.6

（e）教員の熱意

（非常に感じる； 5 ，感じない；1）

高専生 $\cdots \cdots \cdot 4.7 \quad$ 大学生 $\cdots \cdots \cdot 4.7$

(f) 授業目標の理解

（十分理解； 5, 無理解；1)

高専生……3.8 大学生…… 3.5

(g) 関心の高まり

（非常に関心有り；5，関心なし；1）

高専生……4.0 大学生……4.3

（h）シラバスに準拠した授業

（充分実施； 5，無し；1）

高専生……4.2 大学生……4.2

大学の授業アンケートのこの他の設問からも,「良 い授業」とするための本科目の取り組みに対する評価 を読み取ることが出来る。受講の意義については, 非 常に有意義とする学生が $69 \%$, 少し有意義とする学生 が $23 \%$ となっている. 授業時の教員と学生の双方向的 なやりとりが行われたかについては, 非常に図られて いたとする学生が $23 \%$, 少し図られていたとする学生 が $62 \%$, あまり図られていなかったとする学生が $15 \%$ となっている．授業の難易度については, 適切とする 学生が $92 \%$, 少し難しかったとする学生が $8 \%$ であっ た。また，試験の答案に記載された授業に関わる自由 記述からも学生意識を知ることが出来る. 原文の一部 抜粋を以下に示す.

〈高専生〉

1）資格試験の一部免除ということで, 覚える量が 
とても多く, 大変だった. 試験問題については授 業の説明と良くあっていたので良かったと思いま す.

2 ) 発破に関する知識も習得出来たので, 資格試験 も受けてみたいと思います，とても興味のわく内 容でした。

3 ）高専で授業を受けて 5 年目であるが，こんなに 楽しく興味の持てる授業は久しぶりである.

4 ）興味をもって取り組まないと身に付かないこと がわかった。

$5 ）$ 興味を持てた科目なので楽しく授業を受けるこ とが出来たが, 試験に対する覚悟が不足していた. 〈大学生〉

1）この講義を履修することで，爆破施工技術者に 大きく近づくという特権があり，意欲をもって取 り組めた．丁寧な授業は内容が頭に入りやすく非 常に良かった。

2 ）休まず出席しました。薬類を取り扱うという ことで興味があり，おもしろい授業でした．計算 問題が好きでした，実験も体験することが出来, 充実した授業が出来たのではないかと思います.

3 ）この授業は一度も欠席することなく真剣に取り 組めた，授業に関係のあるビデオを流してもらえ たり, 公開実験を見れたのは内容を理解する上で, とても役にたった．教科書で文字を眺めるだけの 授業にはしてほしくなかったので， 4 年間の最後 の授業をこんなに良い体験で終われて良かったと 思っている.

4 ）授業では実験施設を見学し，爆破衝撃を体感す ることが出来, 興味深い話も聞けたので良かった。 法令も勉強して資格もとりたい.

\section{2 授業取り組みの評価}

これらの学生の授業アンケートデータや自由記述か ら, 科目担当者の授業取り組みに対する受講学生の理 解と評価を読みとることが出来る. 大学生, 高専生と もに関心をもって受講し，良い授業とするための授業 担当者の取り組みについても理解が得られたと考えて いる．全体として，大学生の方が授業に対する評価は 高い. 簡潔に要点をまとめて示すために，授業ではパ ワーポイントを使用しているが，高専生においては， 授業の進む速さや，板書きの適切さについて評価が低 い. 大学での授業においては非常勤である担当者の意 識が, デイスカッションを通して知識と学ぶ意欲を高 めさせるための学生への問いかけを躊躇させ, 質疑が 不十分になったことは反省点である．高専生に対する 授業では, 授業中の説明が彼らにとって十分わかりや すいとの評価になっていないことも留意する必要があ る.

図 1 は，履修効果に関わる学期末の成績分布を示し ている，数值は四捨五入している．高専生の方が成績

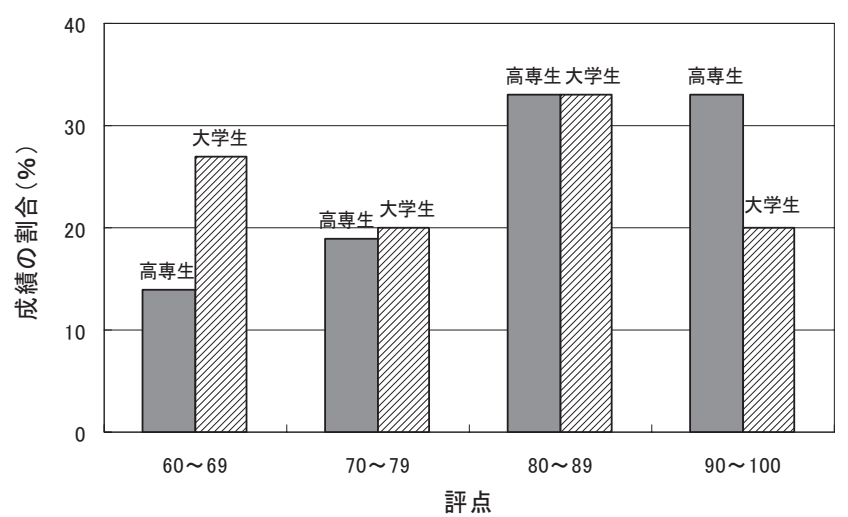

図 1 学期末の成績評点の分布

上位者の割合が多いが，これは試験範囲が関係してい ると考えられる. 大学生は, 学期末試験において, 15 週で学ぶ全範囲が試験範囲となるのに対して, 高専生 においては中間試験を行うことから, 試験勉強のしや すさに関係していると考えられる. 社会の要求レベル を意識しながら，A評価の学生が少なくとも受講生の $1 / 3$ 以上となるように指導したいとする授業担当者の 目標は達成出来ている. しかしながら, 大学生, 高専 生ともに受講のための毎週の自学時間は少なく, 多く の学生が 1 時間未満である。このため, 授業時に行う 資格試験問題演習の課題を自学のための課題として与 えることなどが必要と考えている.

\section{4. 良い授業についての学生意識}

\section{1 学生が選ぶ良い授業の条件}

高専生と大学生の前述の授業評価デー夕の違いは, 授業アンケートの意義や良い授業に関する学生意識に も関係していると考えている. 著者らは, 所属する高 専の学科の学生を含む本科 2 学科 10 クラスの学生（ア ンケート学生数391名）について，良い授業に関する 意識調查を平成19年 2 月〜 3 月に行った。設問では, 学生が意識する良い授業のイメージを具体化するため に, あらかじめ示した11項目の中から 5 項目を選択さ せた. 表 1 は, 高専高学年の 4 年, 5 年, 専攻科の学 生デー夕をまとめたものである. 表中の順位は選択し た割合の多い順を示す.「(4)例題の解答を多く示して, 説明してくれる授業」,「(9)達成感や学ぶ意欲が得ら れる授業」,「(6)質問をしやすい授業」などが共通し て順位が高い。また，「(10)試験では頭に詰め込んだ 量で評価がなされる授業…暗記しておけば点数がとれ る授業」については, その割合は小さく, 学ぶ側の健 全な意識と評価できる。しかしながら，「(7)授業での 理解を深めるために予習課題を出す授業」や「(8)授 業後の理解を深めるために, 復習問題を出す授業」を 評価する割合は小さい.

大学生の授業に関する意識については, 東京大学の 研究グループによって調査がなされ, その概要が平成 19年11月の新聞紙上に示されている ${ }^{9)}$. 全国の大学生 
表 1 「良い授業」に関する学生アンケート結果

\begin{tabular}{|c|c|c|c|c|c|c|c|}
\hline 番号 & 良い授業の条件 & \multicolumn{2}{|c|}{4 年 } & \multicolumn{2}{|c|}{5 年 } & \multicolumn{2}{|c|}{ 専攻科 } \\
\hline ( 1 ) & ノートに写しやすいように, 黒板に板書きがなされる授業 & (5) & 54.3 & (4) & 58.2 & & 42.4 \\
\hline (2) & 「ここは大事だから覚えておくように」と言ってくれる授業 & (4) & 56.8 & (5) & 55.2 & (5) & 51.5 \\
\hline (3) & 暗記しやすいように，整理して教えてくれる授業 & & 32.1 & & 34.3 & & 27.3 \\
\hline (4) & 例題の解答を多く示して, 説明してくれる授業 & (1) & 76.5 & (1) & 73.1 & (1) & 84.8 \\
\hline (5) & 多くの質問を受講する側にして授業への関心を高めてくれる授業 & & 49.4 & & 46.3 & (4) & 54.5 \\
\hline (6) & 質問をしやすい授業 & (3) & 59.3 & (3) & 58.2 & (3) & 66.7 \\
\hline ( 7 ) & 授業での理解を深めるために, 予習課題を出す授業 & & 17.3 & & 11.9 & & 12.1 \\
\hline ( 8 ) & 授業後の理解を深めるために, 復習問題を出す授業 & & 30.9 & & 25.4 & & 36.4 \\
\hline (9) & 達成感や学ぶ意欲が得られる授業 & (2) & 66.7 & (2) & 62.7 & (2) & 75.8 \\
\hline (10) & 試験では, 頭に詰め込んだ量で評価がなされる授業 & & 4.9 & & 7.5 & & 9.1 \\
\hline (11) & 試験では, 考える力で評価がなされる授業 & & 39.5 & & 46.3 & & 39.4 \\
\hline
\end{tabular}

約 4 万 5 千人の回答によるもので，高度な専門知識を 自ら習得するという大学生のイメージから程遠く, 受 け身の傾向が強い現在の学生意識が示されている. 大 学生の多くは「自分で勉強するより, 授業で扱ってほ しい」,「自分のレベルにあった授業」を求めていると いう.

この大学生に対する調査結果と前述の高専生の授業 に関する意識調査結果を重ねてみると，授業に対する 学生の受け身意識を改めさせることが求められる。自 発的な取り組みを学生に促すためには，授業を通して 学ぶことのすばらしさや，自分で考えつくすことが出 来ることの大切さを学生に意識させることが必要であ ることがわかる.

\section{2 学生の受講意欲}

著者らは，良い授業とするためには教える側のみな らず，学ぶ側も心がけることがあると考えている。こ の授業に関する学生意識調査では, 技術者を目指して 学ぶ決意は出来ているか否かの問いがなされている. これに関する高学年のデータを，図 2 に示す。約 70

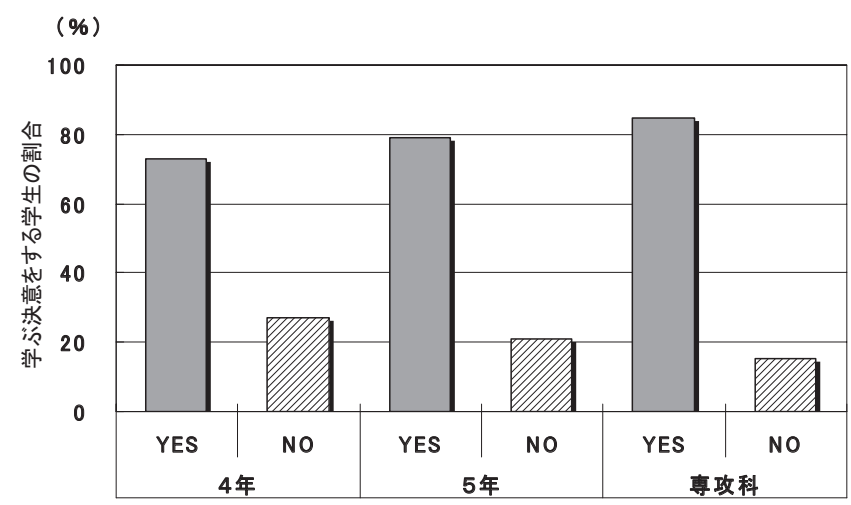

図 2 技術者を目指して学ぶ決意の有無
〜 $85 \%$ の学生は学ぶ決意が出来ていると自己点検し ていることがわかる. 高学年に進むにつれて, その決 意を有する学生の割合は増加し, 専攻科生では約 $85 \%$ となっているが, このことからも低学年における導入 教育 ${ }^{10)}$ の大切さも読みとることが出来る.

\section{3 学生に伝えるべきこと}

当然のことであるが, 授業アンケートなどによって, 教員側の取り組みにその事が反映されているか，との 学生からの指摘が多い，前述のアンケート調査につい ても授業改善に活かしてほしいとの意見も多い。この ため, 調査結果に関する学生への報告文書では, 良い 授業についての著者らの考えを示し，学びに対する意 欲を高め, 考える力を育てる授業の重要さを指摘した. 具体的には，授業を受ける学生に予習課題などを与え て, 自発的な取り組みを促し, 授業での集中力と理解 力を高め, 充実感や達成感を意識させることが大切で あることを伝えた。このような授業を行うためには学 生側も自覚をもって, 自己の能力を高めるための取り 組みが求められることや，授業が教える側と学ぶ側の 相互行為であることも理解しておく必要があることも 伝えた．教員側にも，熱意やコミュニケーション力が 必須となるが，それを受け取ることが十分出来ていな い学生が少なくないことは気になることである。

\section{5.まとめ}

本論文では, 著者らが考える「良い授業の条件」と， それを基に授業を行った専門応用科目での取り組み事 例を示し, 学生の授業アンケート結果の分析から, こ の授業取り組みが評価出来ることを示した．授業取り 組みでは，学びへの意欲を高め，考える力を育てるこ とを重視したが，そのための提案がすでに日本工学教 育協会より出されている報告書にまとめられているこ 
とを知った ${ }^{11)}$. 考える力を育てるための講義での工夫 として示された事項と本論文で示した良い授業とする ための取り組みを対応させると以下のようになる。

1)「講義の目的を明らかにする」,「実践的，具体的 な内容を講義する」などについては，2.2(a) に 記載した取り組みが対応する。

2)「演習重視の講義をする」については，2.2(b) に記載した取り組みが対応する。

3）「一方通行の講義を減らす」,「30\%の討論時間を 設ける」,「事前学習をさせ, 講義では発表を主体と する」などについては，2.2(c) が対応する.

このように，考える力を育てる講義とするための工 夫として示された事項の多くに，本論文で示した授業 取り組みは重なるものである。このことからも，本論 文で示した良い授業の条件とそれを実現するための授 業取り組みは評価できる。学生の授業に対する受け身 意識を取り除き, 良い授業を行うために, 学生意識を 育てることの必要性を再度, 強調しておきたい。そし て, 知識の詰め込みではなくて, 学びに対する心の持 ち方を育てることを意識し, 学生が技術者を目指して 学ぶ決意をするために必要な取り組みを行うことが第 一歩と考えている. 達成感を意識させ, 学生の自己肯 定感, 向上心を育て, 合わせて自己評価能力を高める ことも求められる。

\section{謝 辞}

授業の中の爆発デモ実験は, 熊本大学付属衝撃・極 限環境研究センターの秋丸進助手他, 関係スタッフの 協力のもとに実施された。 また，高専生に対するアン ケート調査では, クラス担任の協力を頂いた。ここに 記して感謝の意を表したい。

\section{参 考 文 献}

1 ）永山裕二：特別講演「大学改革の現状と工学教育
への期待」, 工学教育, $55-1, \mathrm{pp} .80-86,2007$.

2 ) 大輪武司：高等教育機関の教育改革に望むことと 産業界の責任, 工学教育, $51-3$, pp.3-8, 2003.

3 ) 国立高等専門学校協会編 : 高等技術教育フォーラ 么'98総合報告, pp.60-61, 1998.

4 ）熊本日日新聞朝刊掲載インタビュー記事「横山征 次氏に聞く」, 2003. 5.22.

5 ）熊本日日新聞朝刊掲載インタビュー記事「鈴木誠 氏に聞く」, 2008. 3.8.

6 ）瀬沼武秀：グローバル化時代の技術者に期待され る素養, 工学教育, $56-1$, pp.5-10, 2008.

7 ) 中村裕一, 加藤政利, 山浦一郎, 斉藤義侍: 杭頭の 動的破砕制御に関するモデル実験, 土木学会第 8 回構造物の衝撃問題に関するシンポジウム論文 集, pp.209-212, 2006.

8 ）中村裕一：き裂制御爆破工法, 特許第2115305号, 1996.

9 ）熊本日日新聞朝刊掲載記事「東大調査〈受け身姿 勢浮き彫り〉」, 2007. 11. 19.

10）岩坪要：八代高専における初年度技術者教育, 工 学教育, $55-3$, pp. $171-176,2008$.

11）引用文献 6 )の表 4 にその抜粋が記載されている.

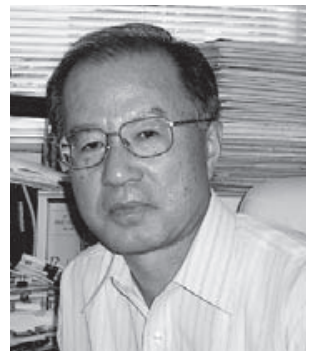

著者 紹 介

\section{中村 裕一}

1976年 熊本大学大学院工学研究科修士 課程修了, 同年熊本大学助手

1985年 八代工業高等専門学校助教授

1988年 工学博士 (九州大学)

1995年 八代工業高等専門学校教授

2003年～2007年

熊本大学非常勤講師

2006年 日本工学教育協会 · 上級教育士 (工学・技術)

現在に至る 